Scientific Journal of Silesian University of Technology. Series Transport Zeszyty Naukowe Politechniki Śląskiej. Seria Transport

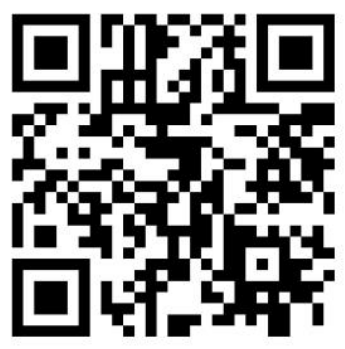

Volume 111

2021

p-ISSN: 0209-3324

e-ISSN: 2450-1549

DOI: https://doi.org/10.20858/sjsutst.2021.111.17

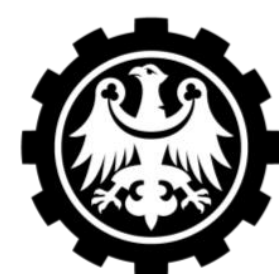

Silesian

University of Technology

Journal homepage: http://sjsutst.polsl.pl

Article citation information:

Wieczorek, A.N. Ensuring appropriate conditions for lubrication of gear transmissions as a priority for maintenance services in industrial transport. Scientific Journal of Silesian University of Technology. Series Transport. 2021, 111, 193-204. ISSN: 0209-3324.

DOI: https://doi.org/10.20858/sjsutst.2021.111.17.

Andrzej N. WIECZOREK ${ }^{1}$

\title{
ENSURING APPROPRIATE CONDITIONS FOR LUBRICATION OF GEAR TRANSMISSIONS AS A PRIORITY FOR MAINTENANCE SERVICES IN INDUSTRIAL TRANSPORT
}

Summary. This paper presents the problem of the operation of gear transmissions in the context of ensuring appropriate lubrication conditions. Damage caused by improper lubrication was discussed. Attention was drawn to the issue of oil contamination. Furthermore, a method for determining the thickness of the oil film of gear wheel teeth was described. There was also performed an analysis of the lubrication conditions of sample gear transmissions of the load, manufacturing technology and surface roughness.

Keywords: gear, wear, lubrication

\section{INTRODUCTION}

Root Cause Analysis (RCA) is often used by industrial plant maintenance services to identify causes of problems or incidents to eliminate them. Due to the use of the analysis of the causes of failures/damages, it is possible to effectively counteract their consequences, thus, significantly affect the economics of the actions taken. This remark applies in particular to the operation of drive units, the service life of which is significantly limited by various forms of

\footnotetext{
${ }^{1}$ Faculty of Mining, Safety Engineering and Industrial Automation, The Silesian University of Technology, Akademicka 2 Street, 44-100 Gliwice, Poland. Email: andrzej.n.wieczorek@polsl.pl.

ORCID: https://orcid.org/0000-0002-8634-7763
} 
wear [1]. Excessive wear [2] of components may, on the one hand, affect the level of safety of the people operating these machines, and on the other hand, cause additional dynamic excitations negatively affecting their service life [3-6] or generating vibroacoustic effects [7-11].

One of the most important components of the drive units is gear transmission $[12,13]$. In the case of these components, teeth fractures at the base usually occur due to fatigue or surface chipping. However, if proper lubrication conditions are not ensured, that is, the layer separating the mating surfaces does not have a sufficient thickness, the wear of these surfaces may be intensified.

This paper presents a method of determining the lubrication conditions of teeth in gear transmissions, which can be used by maintenance services to predict possible damage to gear teeth caused by improper lubrication conditions, as an element of the RCA analysis aimed at ensuring proper operating conditions. Knowledge of the parameters characterising the conditions of lubrication of the teeth allows taking preventive actions, for example, using appropriate lubricants or reducing the permissible loads.

\section{DAMAGE TO TEETH CAUSED BY INADEQUATE LUBRICATION}

In the case of gear transmissions, the elements particularly vulnerable to damage caused by improper lubrication [1] are primarily gear teeth. These elements are required to meet demanding requirements concerning strength and service life. However, they are exposed to:

- surface seizure (adhesive wear) caused, for example, by the improper choice of lubricant,

- surface scratches caused by the presence of single hard grains, for example, sand (Figure 1A),

- local overheating of tooth surfaces due to insufficient amount of lubricant (Figure 1B),

- abrasive wear caused by improper lubrication conditions (Figure 1C),

- fatigue chipping of the surface (Figure 1D).

Lubricants, similarly to components of machines and other equipment, are subject to degradation processes; this occurs due to the action of high temperatures and oxygen. During the operation of industrial gear transmissions, the content of solid impurities in oils and greases usually increases, significantly affecting the intensity of wear of mating surfaces of teeth and rolling bearings. Figure 2 shows the results of the analysis of the content of solids and iron as a function of the operating time for gear transmissions used in armoured face conveyors and belt conveyors in the mining industry [2]. It can be noticed in the Figures that the content of solids and iron increases along with the increase in the operating time and that the differentiation in the content depends on the type of machine. However, it should be mentioned that the durability of surfaces of friction pairs depends not only on the conditions of their operation but also on the correct design and selection of parameters characterising the load, as well as on the material and lubricating properties. 


\section{PARAMETERS CHARACTERISING THE LUBRICATING PROPERTIES OF OILS}

The main purpose of lubrication [3] is to reduce the friction of mating surfaces by creating a layer of lubricant. It is advisable to form an oil film layer with a thickness that allows separating the protrusions in the mating surfaces.

The parameter characterising the separation layer is the minimum thickness of the lubricant layer $\left(h_{\min }\right)$, which is formed in conditions of the electrohydraulic lubrication (the diagram showing the elastohydrodynamic contact zone is presented in Figure 3). The thickness of the oil film depends on some design and operational factors, as well as on the parameters of the lubricant (this issue is discussed in detail in [14]). In practice, the method specified in ISO/TR 15144-1:2014 (E) standard is often used to calculate the minimum thickness of the lubricant layer $h_{\min }$ in gear teeth [15]. In this standard, calculations of the relative thickness of oil film $\lambda$ are usually performed only for 5 points of the engagement section (points A, B, C, D and E shown in Figure 4). However, it is possible to calculate the parameter $\lambda$ also for other points of the engagement section.

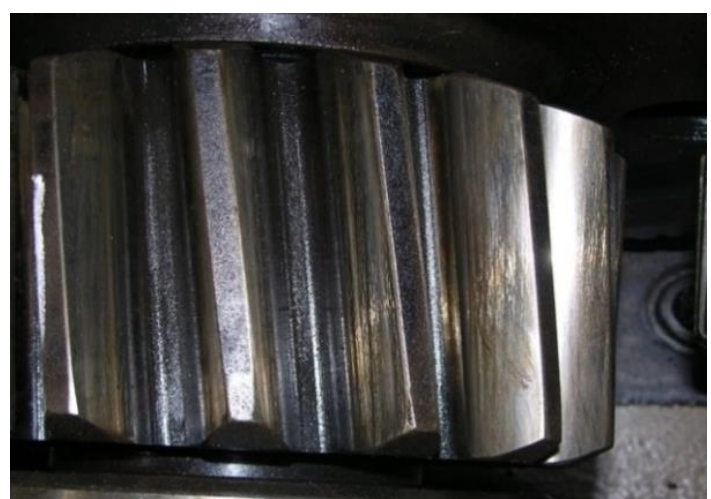

A

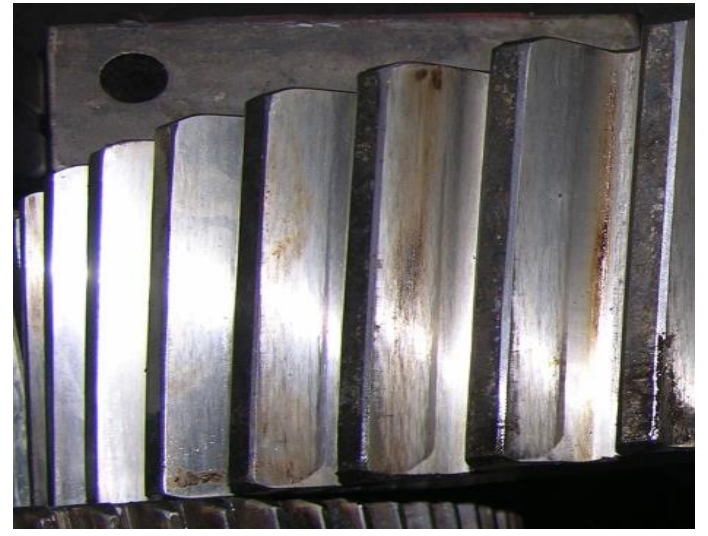

$\mathrm{C}$

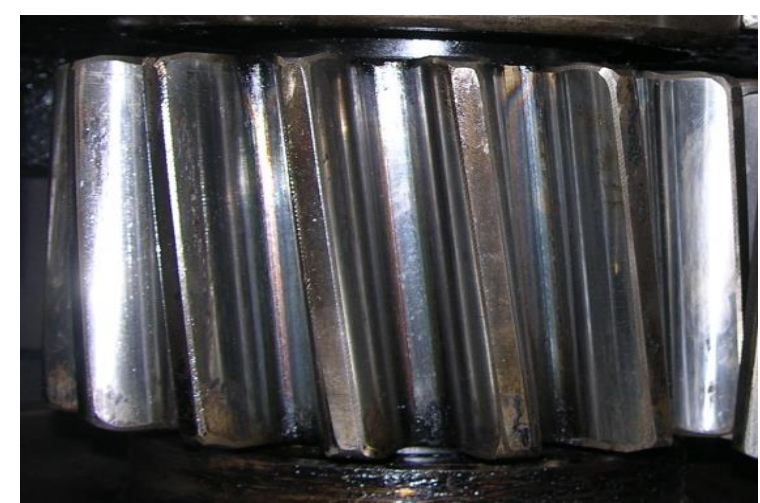

B

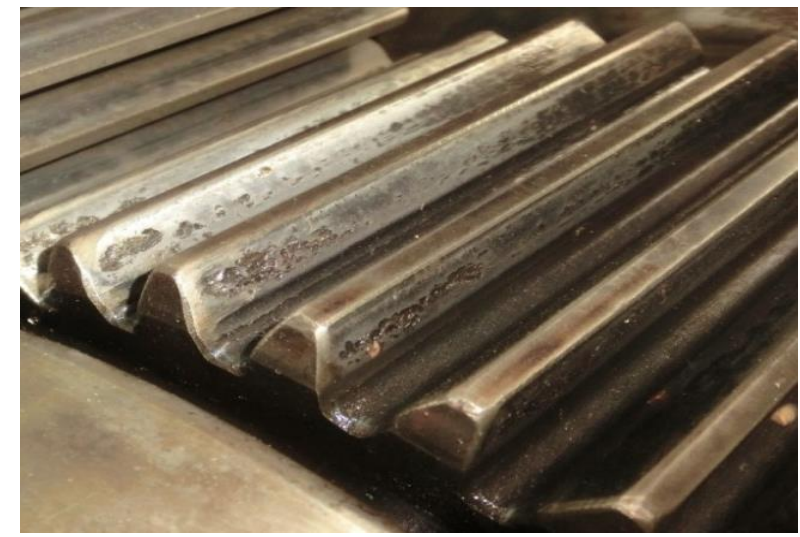

$\mathrm{D}$

Fig. 1. Examples of damage to teeth in industrial gear transmissions: A - surface scratches, $\mathrm{B}-$ signs of overheating, $\mathrm{C}$ - abrasive wear, D - pitting 
Lubrication conditions depend primarily on the roughness of the mating surfaces because the thickness of the oil film may be smaller than the height of the protrusions. In such a situation, the type of friction will be unfavourable (mixed or boundary friction). The parameter characterising the type of friction between the mating surfaces is the relative thickness of oil film (parameter $\lambda$ ), determined by the following relationship [16]:

$$
\lambda=\frac{h_{\min }}{\sqrt{R q_{1}^{2}+R q_{2}^{2}}}
$$

where:

$R q_{1,2}$ - surface roughness.

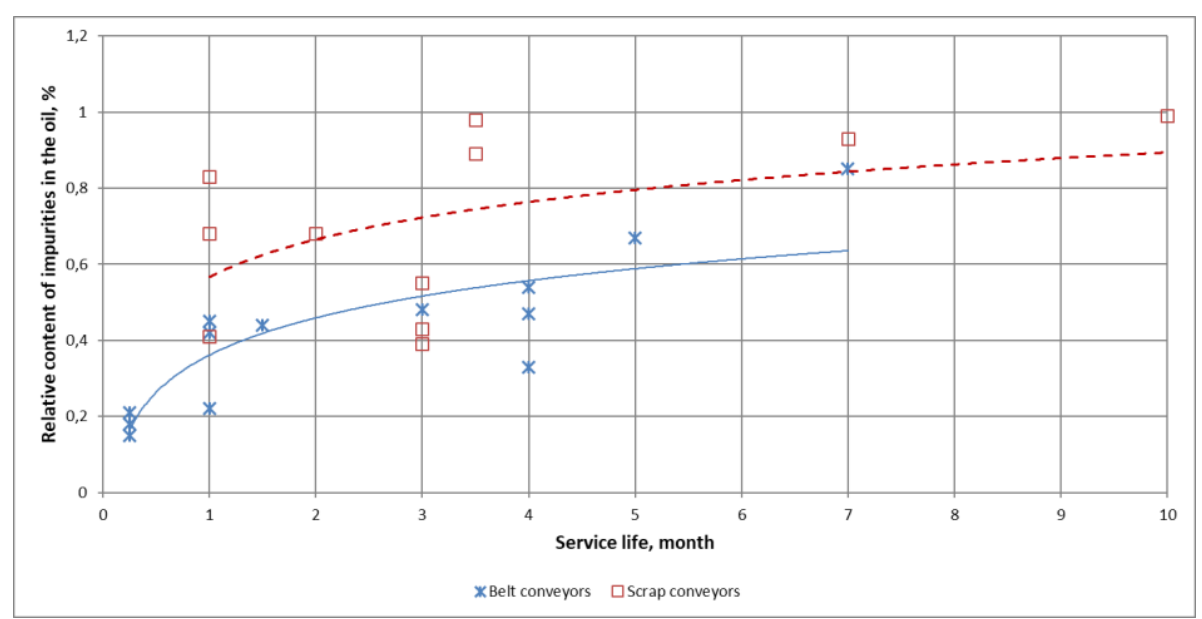

A

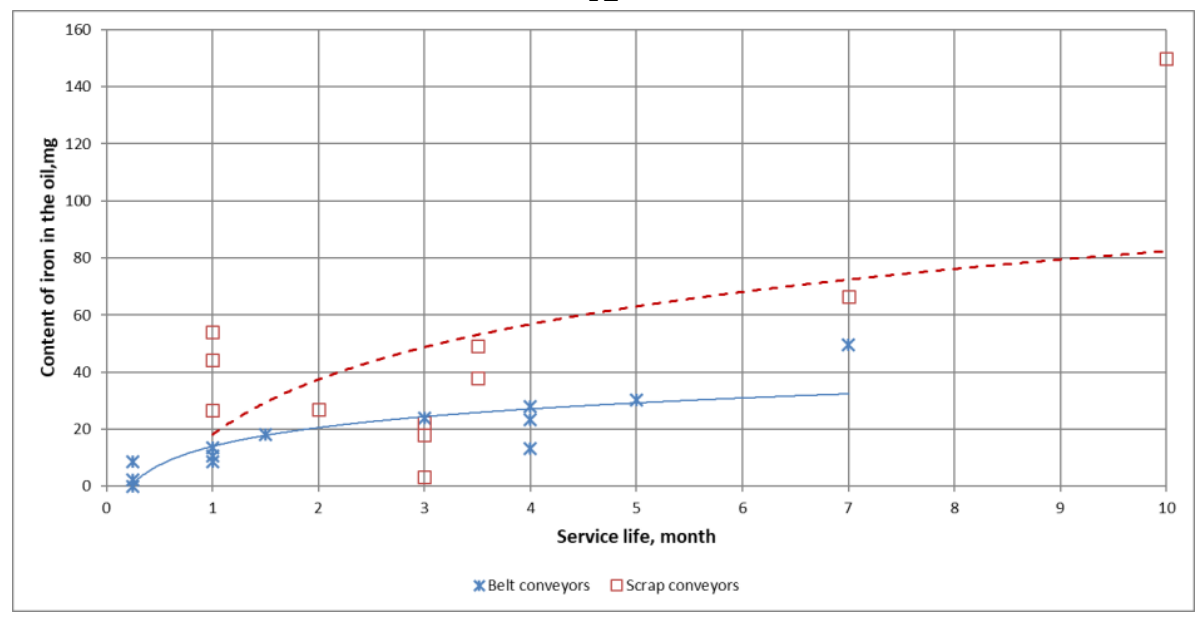

B

Fig. 2. Plots of the content of impurities (A) and iron (B) in oil as a function of operating time, determined for gear transmissions of belt conveyors and armoured scrap conveyors 
In the range of values $\lambda=(0-1)$, there occurs mixed boundary friction (for the parameter Ra, this range will be $\lambda=(0-0.8))$. In the range of the relative value of oil film thickness $\lambda=(1-3)$, the predominant type of friction is mixed friction (for the parameter Ra, this range will be $\lambda=(0.8-2.4)$, whereas in the range of $\lambda=<3-10>$ the conditions of EHD lubrication are created (for the parameter $\mathrm{Ra}$, this range will be $\lambda=(2.4-8)$ ). These conditions are characterised by the formation of an oil film layer with a thickness exceeding the height of surfaces irregularities. Above the relative value of the oil film thickness $\lambda>10$, there occurs liquid hydrodynamic friction (for the parameter Ra, this range will be $\lambda>8$ ) $[16,17]$.

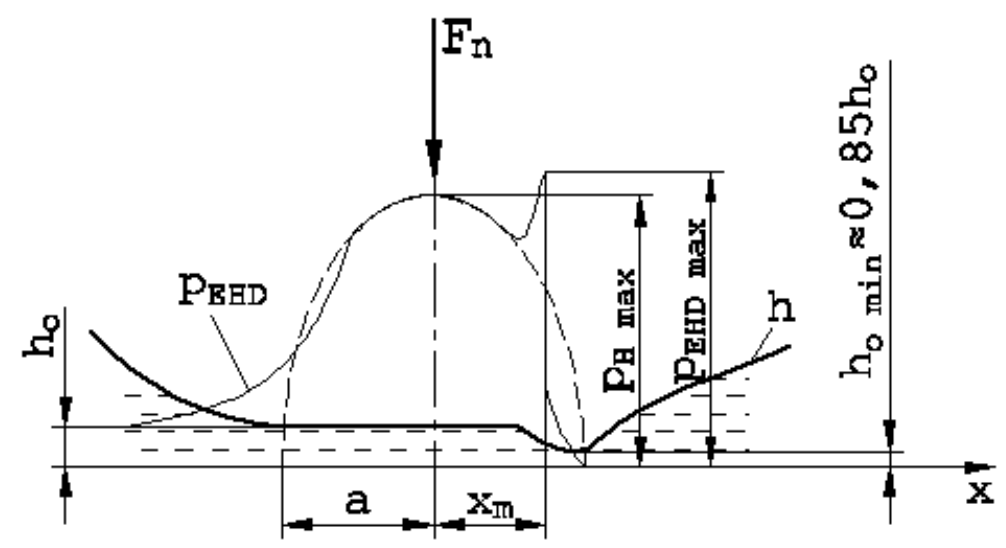

Fig. 3. Pressure distribution $\mathrm{p}_{\mathrm{EHD}}$ and the shape of the lubrication gap $\mathrm{h}$ in the conditions of elastohydrodynamic contact (EHD) between mating surfaces [16]

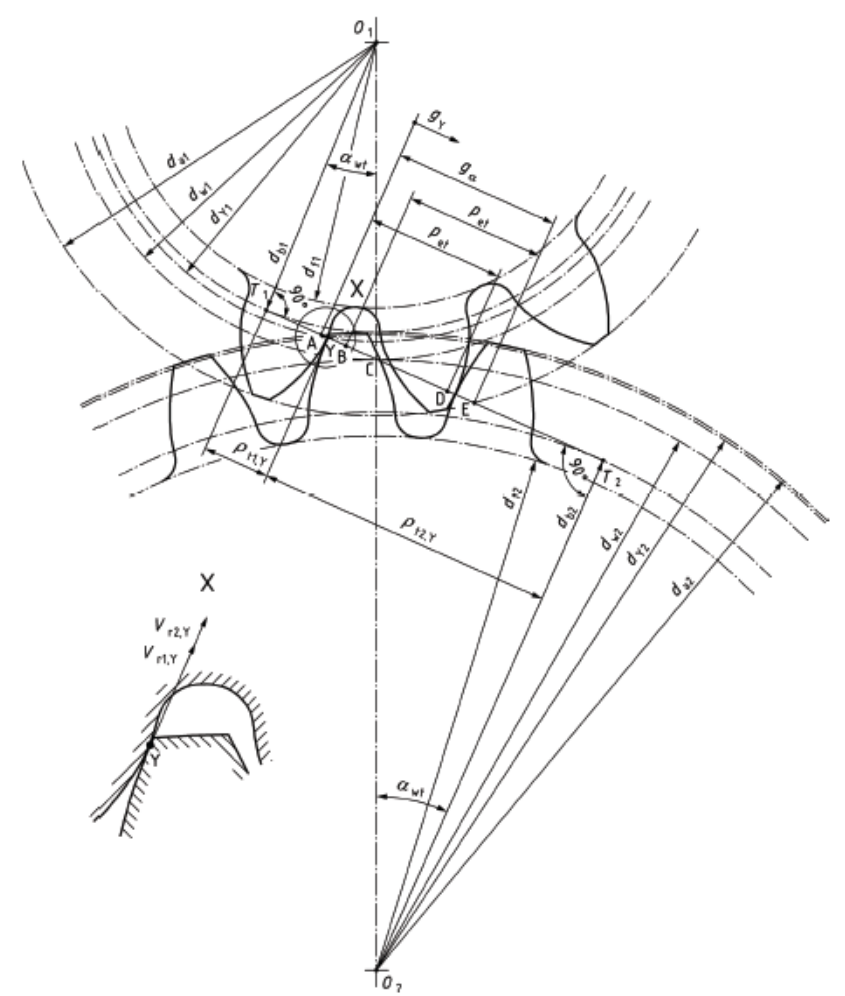

Fig. 4. Geometry of a gear wheel with an external involute profile 
The thickness of the oil film, and thus, the lubrication conditions of gear transmissions, is affected, inter alia, by the following factors:

- location of the contact point in the engagement section of the mating teeth,

- variable number of pairs of teeth in meshing,

- nominal and instantaneous loads,

- surface roughness,

- rotational speed of gears,

- oil viscosity grade.

Figure 5 shows results of calculations (performed according to ISO/TR 15144-1:2014(E)) of the relative thickness of oil film $\lambda$ as a function of the position of gear wheels of a sample gear transmission in the engagement section (for the needs of the analysis, the parameter $\lambda$ was determined for 106 points of the engagement section) for a fixed (nominal) load. In the analysis, there were used parameters characterising the teeth of the second stage of the right angle spur planetary gear transmission with the gear ratio $i=39$. Gear wheels of this gear transmission were made of alloy steels that were subjected to thermal and thermochemical treatment and then ground (accuracy class 6 according to PN-ISO 1328 and roughness $R a=0.8 \mu \mathrm{m}$ were obtained). In Figure 5, there can be easily noticed, a stepwise change in the thickness of the oil film, associated with the change in the number of pairs of teeth being engaged. The lowest values of the oil film thickness are observed for the inner single-tooth engagement point (point B in Figure 5).

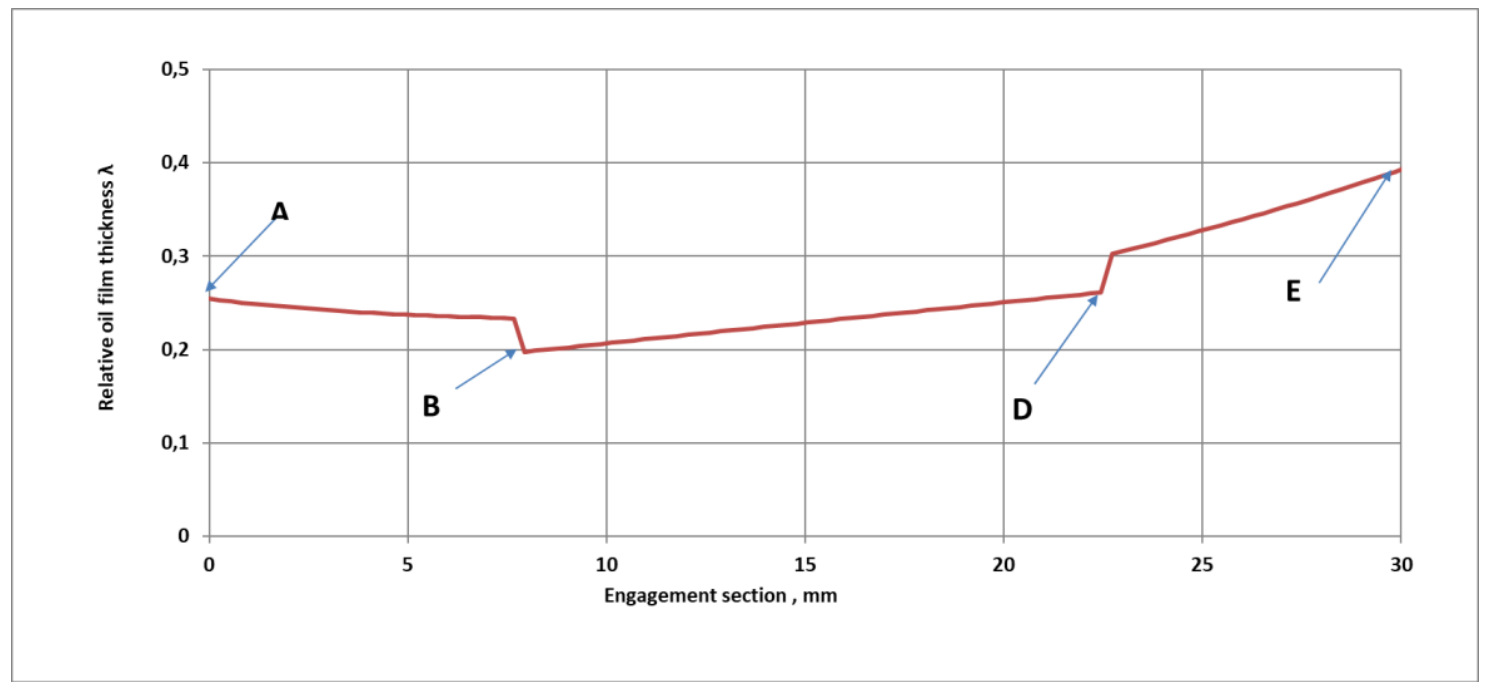

Fig. 5. The plot of the relative thickness of oil film $\lambda$ as a function of the position in the engagement section for the second stage of the right angle spur planetary gear transmission

Another important factor that affects lubrication conditions is the nominal load of a given stage of the gear transmission. Figure 6 shows plots of the relative thickness of oil film $\lambda$ as a function of the power of the drive motor of the second stage of the right angle spur planetary gear transmission (calculations considered the value of the torque and the gear ratio for a given stage) for different viscosity grades of the lubricating oil. In this Figure, it is easy to note that satisfactory lubrication conditions can be obtained only in a fairly narrow range of values of the transmitted power and oil viscosity. 
During the operation of drives of machines, there are frequent changes in the instantaneous load (sample plot showing the variability of the load of the gear transmission of an armoured face conveyor is presented in Figure 7). The variability of the load causes some fluctuations in the thickness of the oil film, and the value of parameter $\lambda$ take place during the operation. These changes are relatively large because, as shown in Figure 8, they can lead to variations in the value of the parameter $\lambda$ up to 0.15 .

Typically, problems with lubrication relate to the highest stages of a gear transmission, which have a higher gear ratio and load torque than the lower stages. Figure 9 shows the results of the calculations of the relative thickness of oil film $\lambda$ for a 3-stage spur gear transmission at point $\mathrm{B}$ of the engagement section. This Figure clearly shows that lubrication conditions deteriorate along with an increase in the gear ratio.

Lubrication conditions can be improved primarily by reducing the roughness of surfaces of gear wheel teeth through process changes. This can be seen in Figure 10, which shows the results of calculations for the relative thickness of oil film $\lambda$ for the previously analysed second stage of the right angle spur planetary gear transmission. This Figure shows plots of the relative thickness of oil film $\lambda$ depending on the parameter Ra for various viscosity grades, determined for the second stage of the right angle planetary gear transmission operating at the assumed drive motor power of $450 \mathrm{~kW}$.

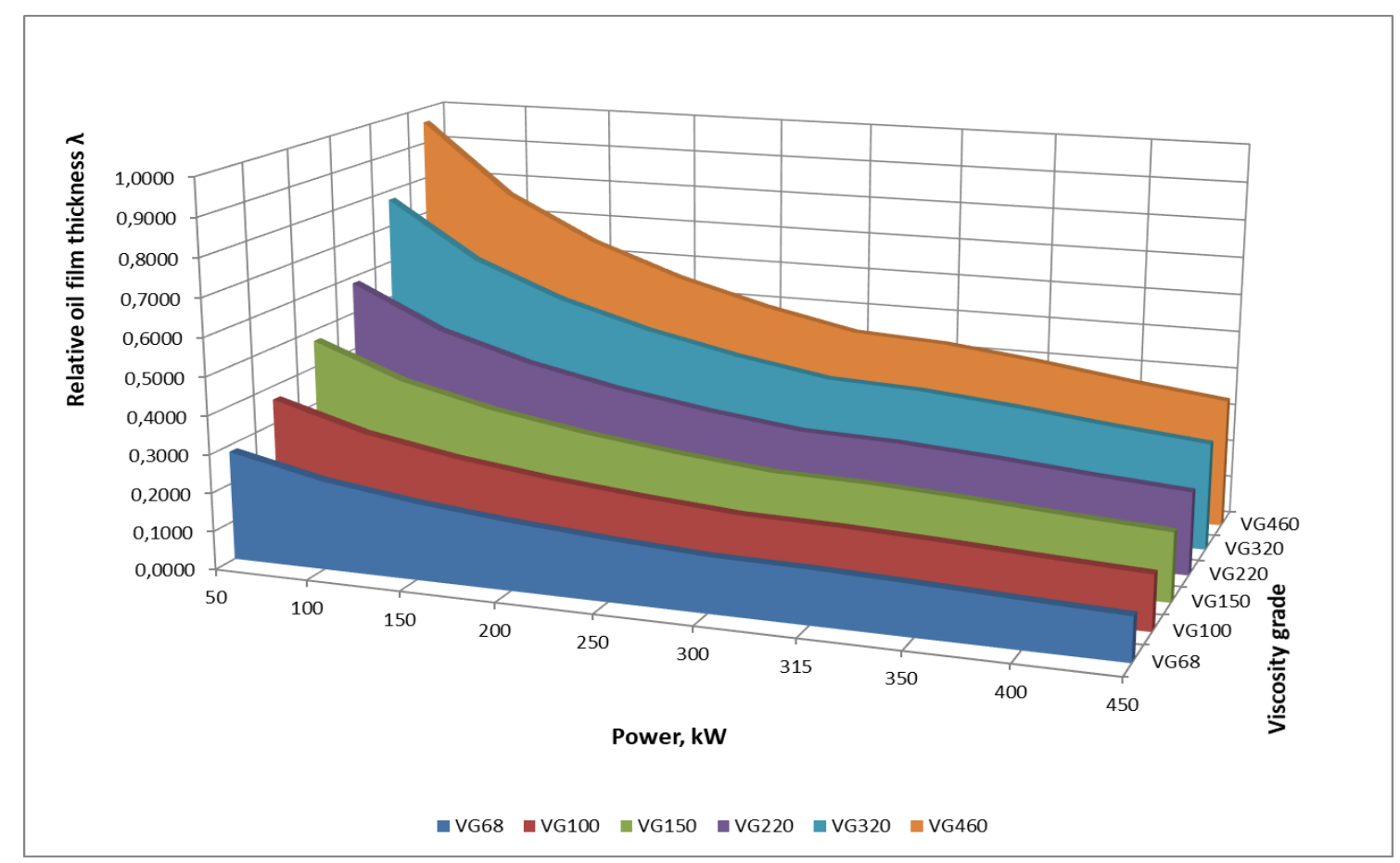

Fig. 6. Plots of the relative thickness of oil film $\lambda$ at point $B$ of the engagement section as a function of the power of the drive motor and the viscosity grade (the results obtained for surface roughness $R a=0.6 \mu \mathrm{m}$ ) 


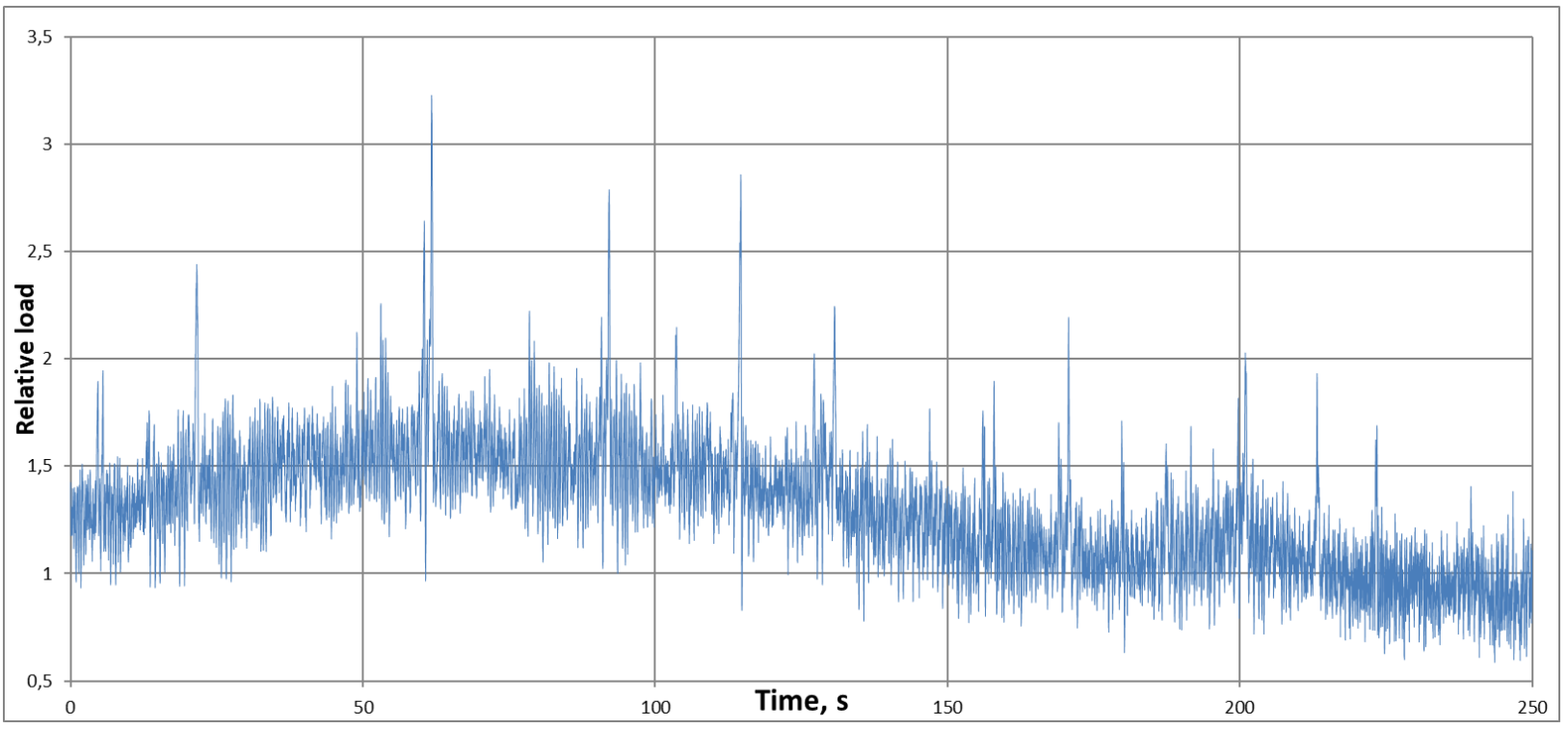

Fig. 7. A sample plot of the values of the instantaneous load in relation to the nominal load of the right angle planetary gear transmission of an armoured face conveyor

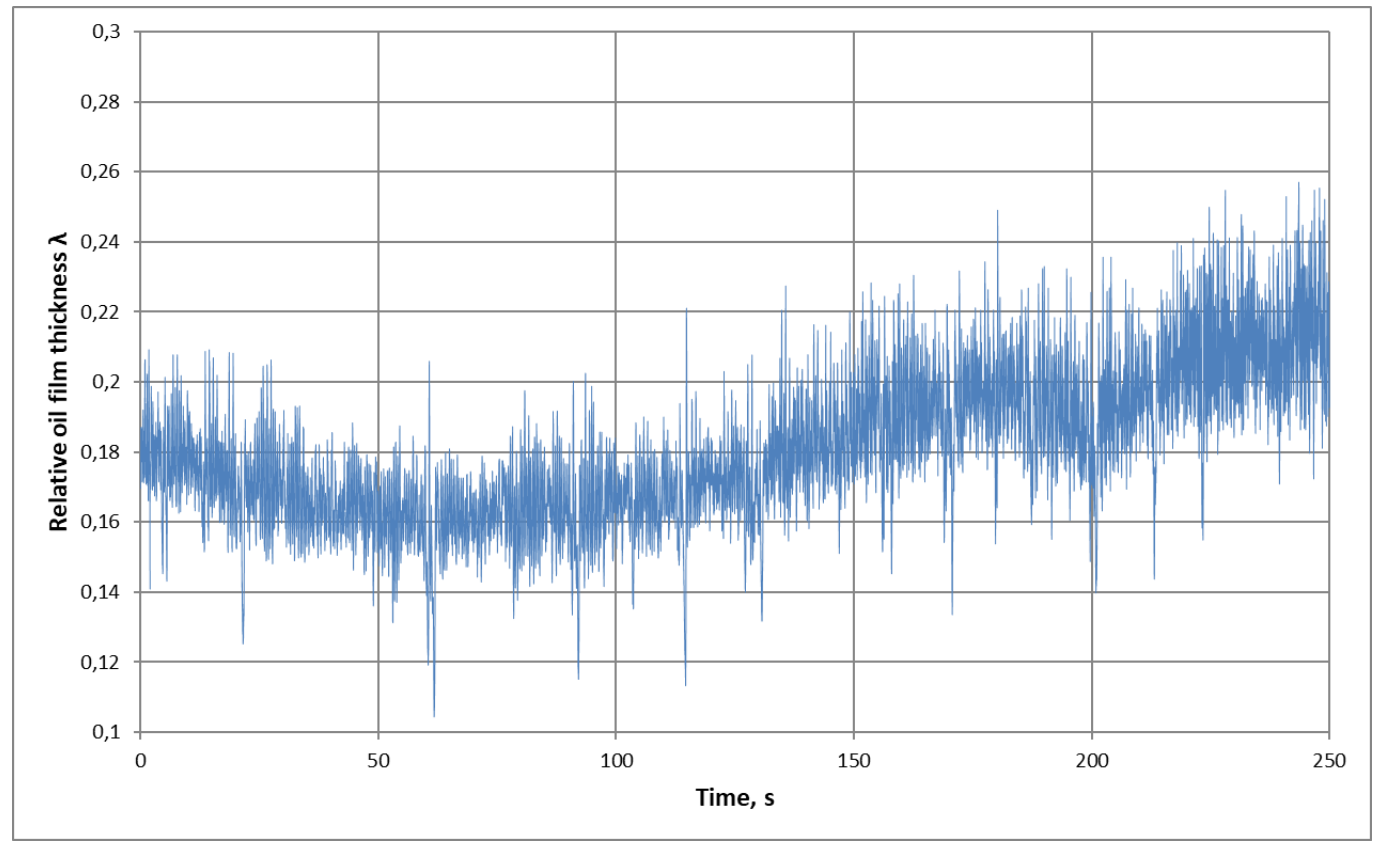

Fig. 8. Instantaneous relative values of the thickness of oil film $\lambda$ determined at point $B$ of the engagement section of the right angle planetary gear transmission

Similarly to Figure 6, the mixed lubrication conditions shown in Figure 10 are only within a fairly narrow range of values of the parameter $\mathrm{Ra}$ and kinematic viscosity. For a typical roughness of surfaces of the teeth subjected to profile grinding, the analysed pair of teeth operate under boundary lubrication conditions. 


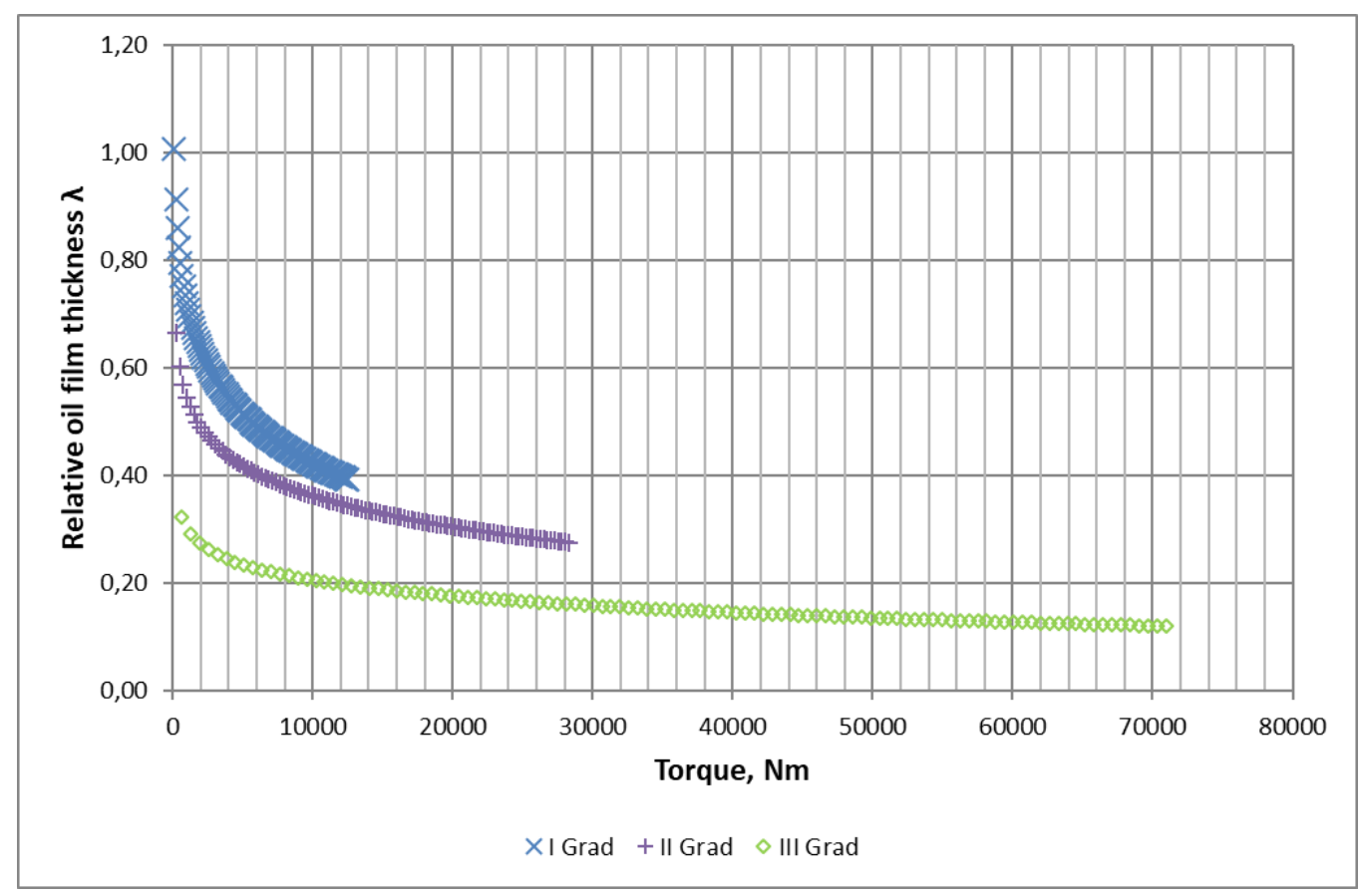

Fig. 9. Plots of the relative thickness of oil film $\lambda$ as a function of the gear ratio, determined for a 3-stage spur gear transmission used in belt conveyors

When analysing lubrication conditions, the direction of measuring the parameter $R a$ should also be considered. As can be seen in Figure 11, there is a variation in the roughness depending on whether the measurement is carried out in the direction of the pitch line or perpendicular to it (along the tooth profile). In the case of the planetary gear transmission subject to the analysis, the value of the parameter Ra measured in the direction of the pitch line was $0.21 \mu \mathrm{m}$, while in the direction perpendicular to it $-0.81 \mu \mathrm{m}$. Figure 12 shows the impact of the direction of measuring the roughness on the plots of the relative thickness of oil film $\lambda$ at point $\mathrm{B}$ as a function of the position in the engagement section for the second stage of the right angle spur planetary gear transmission.

\section{CONCLUSION}

As a part of this study, there was presented, a possibility of using a modified calculation method based on the ISO/TR 15144-1:2014 (E) standard for determining the lubrication conditions of typical industrial gear transmissions used in drives of conveyors in industrial transport. The analysis covered primarily the second spur gear stage of the right angle spur planetary gear transmission with the gear ratio $i=39$, as well as a 3 -stage spur gear transmission. The selected method can be used by maintenance services in RCA to determine the optimal lubrication conditions for given operating conditions of the gear transmission. The decision regarding the choice of operating conditions, type of lubricant and requirements concerning the roughness of the surface of gear wheels should be taken only after the results of these calculations have been obtained. Such an approach can improve the service life and the time of failure-free operation of drives of industrial transport machines. 


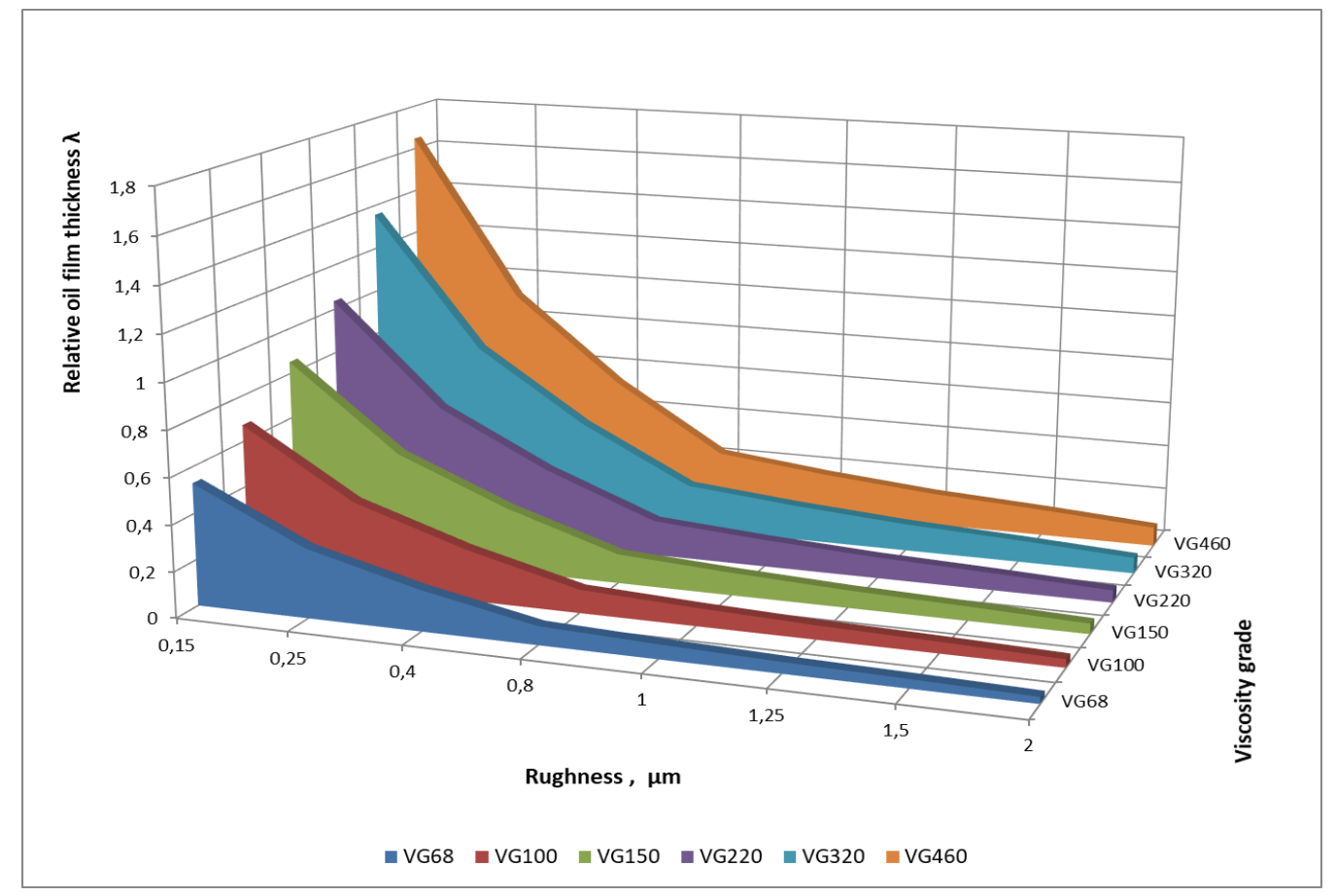

Fig. 10. Plots of the relative thickness of oil film $\lambda$ at point $B$ of the engagement section as a function of the roughness and the viscosity grade for a right angle planetary gear transmission (the results obtained for drive motor power $P=450 \mathrm{~kW}$ )

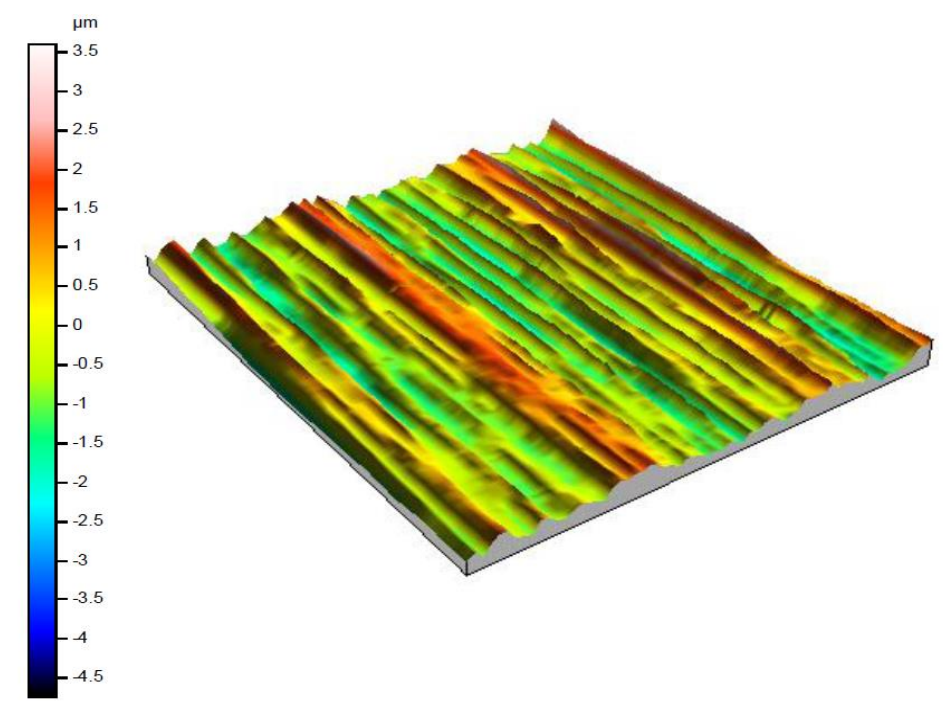

Fig. 11. View of the profilogram of the tooth surface subjected to profile grinding 


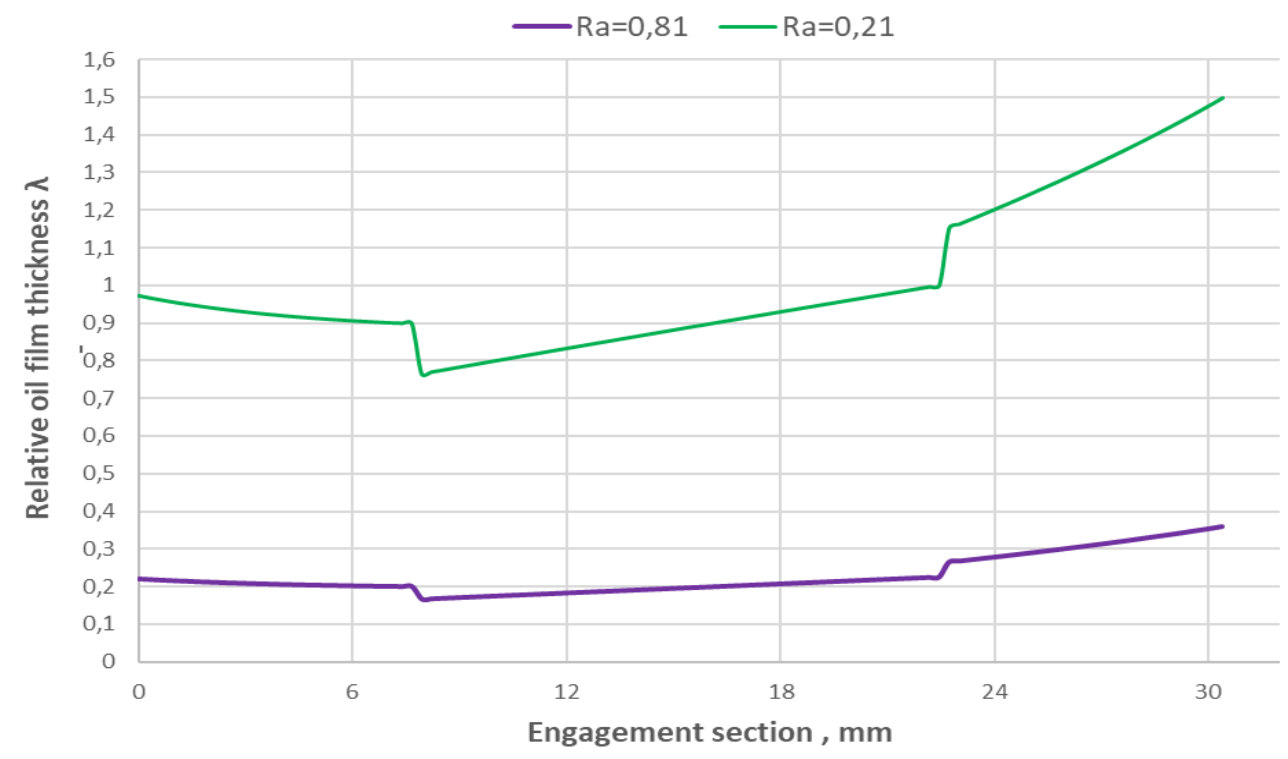

Fig. 12. Plots of the relative thickness of oil film $\lambda$ as a function of the position in the engagement section for the second stage of the right angle spur planetary gear transmission, determined for the roughness $R a=0.21 \mu \mathrm{m}$ (direction consistent with the pitch line) and for the roughness $R a=0.81 \mu \mathrm{m}$ (direction perpendicular to the pitch line)

\section{References}

1. Bartz Wilfried. 1989. Getriebeschmierung. [In German: Gear lubrication]. Ehningen: Expert Verlag. ISBN: 38-1690-404-1.

2. Spałek Jacek. 2003. Problemy inżynierii smarowania maszyn w górnictwie. [In Polish: Problems of machinery lubrication engineering in mining]. Gliwice: Publishing house of the Silesian University of Technology. ISBN: 83-7335-225-2.

3. Hebda Michał. 2007. Procesy tarcia, smarowania i zużywania maszyn. [In Polish: Processes of friction, lubrication and wear of machines]. Warsaw-Radom: PIB. ISBN: 978-83-7204-556-0.

4. Nadolny Karol. 1999. Tribologia kół zębatych: zagadnienia trwałości i niezawodności. [In Polish: Gear tribology: durability and reliability issues]. Poznan-Radom: PIB. ISBN: 83-7204-077-X.

5. Michalski R., S. Wierzbicki. 2008. „An analysis of degradation of vehicles in operation”. Eksploatacja i Niezawodnosc - Maintenance and Reliability 1: 30-32.

6. Mazurkiewicz D. 2014. „Computer-aided maintenance and reliability management systems for conveyor belts". Eksploatacja i Niezawodnosc - Maintenance and Reliability 16(3): 377-382.

7. Madej Henryk, Piotr Czech, Łukasz Konieczny. 2003. „Wykorzystanie dyskryminant bezwymiarowych w diagnostyce przekładni zębatych”. Diagnostyka 28: 17-22. ISSN: 1641-6414. 
8. Medvecka-Benova Silvia, Peter Bigos. 2013. „Analysis of noise reduction of gear transmissions". In: 13th SGEM GeoConference on Ecology, Economics, Education And Legislation. SGEM2013 Conference Proceedings 1: 57-62. DOI: 10.5593/SGEM2013/BE5.V1/S20.008.

9. Maláková Silvia, Michal Puškár, Peter Frankovský, Samuel Sivák, Maroš Palko, Miroslav Palko. 2020. „Meshing Stiffness - A Parameter Affecting the Emission of Gearboxes". Applied Sciences 10(3): 1-12. DOI: 10.3390/app10238678.

10. Czech Piotr. 2011. „Diagnosing of disturbances in the ignition system by vibroacoustic signals and radial basis function - preliminary research". Communications in Computer and Information Science 239: 110-117. DOI: https://doi.org/10.1007/978-3-642-246609_13. Springer, Berlin, Heidelberg. ISBN: 978-3-642-24659-3. ISSN: 1865-0929. In: Mikulski Jerzy (eds), Modern transport telematics, 11th International Conference on Transport Systems Telematics, Katowice Ustron, Poland, October 19-22, 2011.

11. Czech Piotr. 2013. „Diagnosing a car engine fuel injectors' damage”. Communications in Computer and Information Science 395: 243-250. DOI: https://doi.org/10.1007/978-3642-41647-7_30. Springer, Berlin, Heidelberg. ISBN: 978-3-642-41646-0; 978-3-64241647-7. ISSN: 1865-0929. In: Mikulski Jerzy (eds), Activities of transport telematics, 13th International Conference on Transport Systems Telematics, Katowice Ustron, Poland, October 23-26, 2013.

12. Maláková Silvia, Matej Urbanský, Gabriel Fedorko, Vieroslav Molnár, Samuel Sivak. 2021. „Design of Geometrical Parameters and Kinematical Characteristics of a Noncircular Gear Transmission for Given Parameters". Applied Sciences 11(3): 1-23. DOI: 10.3390/app110311000.

13. Maláková Silvia, Peter Frankovský, Daniela Harachová, Vojtech Neumann. 2019. „Design of constructional optimisation determined for mixed truck gearbox”. AD ALTA Journal of Interdisciplinary Research 9: 414-417. ISSN: 1804-7890.

14. Wiśniewski Michał. 2000. Elastohydrodynamische Schmierung. Renningen-Malmsheim: Expert Verlag, ISBN: 978-3-8169-1745-8.

15. ISO/TR 15144-1:2014 (E) Calculation of micropitting load capacity of cylindrical spur and helical gears - Part 1: Introduction and basic principles.

16. Dowson Duncan, Gordon Higginson. 1976. Elastohydrodynamic lubrication. OxfordLondon: Pergamon Press. ISBN: 9781483181899

17. Hamrock Bernard, Duncan Dowson. 1981. Ball Bearing Lubrication. New York, Chichester, Brisbane, Toronto, Singapore: John Wiley \& Sons. ISBN: 9780471035534.

Received 11.03.2021; accepted in revised form 09.05.2021

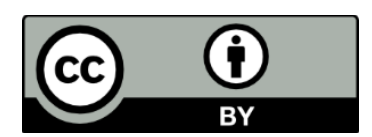

Scientific Journal of Silesian University of Technology. Series Transport is licensed under a Creative Commons Attribution 4.0 International License 